\title{
Molecular identification of the first Galapagos fur seal (Arctocephalus galapagoensis) reported on the central coast of Oaxaca
}

\section{Identificación molecular del primer lobo fino de Galápagos (Arctocephalus galapagoensis) registrado en la costa central de Oaxaca}

\author{
Carlos Javier Tamayo-Millán ${ }^{1}$, Miguel Ángel Ahumada-Sempoal², Adriana Cortés-Gómez \\ Ivon Marcela Chacón-Romo Leroux ${ }^{4}$, Dennis Bermúdez-Díaz ${ }^{4}$, Valentina Islas-Villanueva ${ }^{5 *}$ \\ ${ }^{1}$ Programa de Maestría en Ciencias-Ecología Marina, División de Estudios de Posgrado, Universidad del Mar, \\ campus Puerto Ángel, Cd. Universitaria, s/n, 70902, Puerto Ángel, Oaxaca, Mexico. \\ 2 Instituto de Recursos, Universidad del Mar, Cd. Universitaria, s/n, 70902, Puerto Ángel, Oaxaca, Mexico. \\ ${ }^{3}$ Laboratoire d'Écologie Systématique et Évolution, Université Paris-Saclay, 15 Rue Georges Clemenceau, \\ Orsay, 91400, France. \\ ${ }^{4}$ Centro Mexicano de la Tortuga, km 10 Carretera Puerto Ángel-San Antonio, Mazunte, Santa María \\ Tonameca, 70946, Oaxaca, Mexico. \\ ${ }^{5}$ CONACYT-Universidad del Mar, Cd. Universitaria s/n, Oaxaca, 70902, Mexico.
}

* Corresponding author. E-mail: v.islas.villanueva@gmail.com

\begin{abstract}
Several sightings of different pinniped species have been recorded outside their typical areas of distribution. In May 2019, pinniped yearlings were sighted on 4 occasions on the central coast of Oaxaca, Mexico. One of them was found injured in La Escobilla (Oaxaca, Mexico) and was transported immediately to the Centro Mexicano de la Tortuga for rehabilitation. Visual identification of the species was inconclusive, as young individuals of several fur seal species can be very similar. A molecular analysis was thus performed to confirm the species. DNA was extracted from the individual, and a fragment of the mitochondrial DNA control region was sequenced and aligned with several sequences of other fur seal species. A parsimony analysis was performed, and the tree revealed that the individual was a Galapagos fur seal, Arctocephalus galapagoensis. This is the first record of this species on the central coast of Oaxaca. The atypical presence of this species in the country could be related to high sea surface temperatures associated with events such as El Niño.
\end{abstract}

Key words: atypical sighting, mtDNA control region, El Niño, pinnipeds, species identification.

RESUmen. Diversos avistamientos de diferentes especies de pinnípedos han sido registrados fuera de sus habituales áreas de distribución. En mayo de 2019, se avistaron, en 4 ocasiones, pinnípedos de aproximadamente un año de edad en la costa central de Oaxaca, México. Uno de los individuos se encontró herido en la localidad de La Escobilla (Oaxaca, México) y fue trasladado inmediatamente al Centro Mexicano de la Tortuga para su rehabilitación. La identificación visual de la especie fue inconclusa debido a que los individuos juveniles de diversas especies de lobo fino pueden ser muy parecidos. Por lo tanto, se realizó un análisis molecular para confirmar la especie. Se extrajo ADN del individuo y se secuenció un fragmento de la región control del ADN mitocondrial. La secuencia del ADN se alineó junto con secuencias de otras especies de lobo fino. Se realizó un análisis de parsimonia, y el árbol confirmó que el individuo era un lobo fino de Galápagos, Arctocephalus galapagoensis. Este es el primer registro de la especie en la costa central de Oaxaca. La presencia atípica de esta especie en el país podría estar relacionada con altas temperaturas superficiales del mar causadas por eventos como El Niño.

Palabras clave: avistamiento atípico, región control del ADNmt, El Niño, pinnípedos, identificación de especies.

\section{INTRODUCTION}

Four pinniped species belonging to 2 families can be found along the Pacific coast of Mexico, the northern elephant seal, Mirounga angustirostris (Gill 1866), and the harbor seal, Phoca vitulina richardsi (Gray 1864), in the Phocidae family, and the California sea lion, Zalophus californianus (Lesson 1828), and the Guadalupe fur seal, Arctocephalus philippii townsendi (Peters 1866), in the Otariidae family. Pinniped populations are associated with geographic areas like coasts and islands where different food resources are available (Riedman 1990). Access to these resources is affected by the

\section{INTRODUCCIÓN}

A lo largo de la costa mexicana del Pacífico se pueden encontrar 4 especies de pinnípedos representadas en 2 familias, el elefante marino del norte, Mirounga angustirostris (Gill 1866), y la foca de puerto, Phoca vitulina richardsi (Gray 1864), de la familia Phocidae, y el lobo marino de California, Zalophus californianus (Lesson 1828), y el lobo fino de Guadalupe, Arctocephalus philippii townsendi (Peters 1866), de la familia Otariidae. Las poblaciones de pinnípedos están asociadas a áreas geográficas donde se presentan diferentes fuentes de recursos alimentarios, como 
temperature of the ocean, strongly restricting the distribution of populations (Trillmich et al. 1991). Despite geographical restrictions, several sightings of different pinniped species have been recorded outside their typical areas of distribution, even at distances greater than hundreds or thousands of kilometers. Some atypical records in Mexico include Arctocephalus australis (Zimmerman 1783) in Oaxaca (Villegas-Zurita et al. 2016), Eumetopias jubatus (Schreber 1776) in Colima (Ceballos et al. 2010, Gallo-Reynoso et al. 2020), Zalophus wollebaeki (Sivertsen 1953) in Chiapas, and Arctocephalus galapagoensis (Heller 1904) in Guerrero, Chiapas, and Michoacán (Aurioles-Gamboa et al. 2004, Páez-Rosas et al. 2017).

The Galapagos fur seal (GFS), A. galapagoensis, is the smallest of the fur seals. Its sexual dimorphism is very subtle in comparison with other otariids. Males reach sizes between 1.5 and $1.6 \mathrm{~m}$ long and weigh between 60.0 and $68.0 \mathrm{~kg}$. Females can reach $1.3 \mathrm{~m}$ long and weigh between 21.5 and $33.0 \mathrm{~kg}$. Pups weigh between 3.0 and $4.0 \mathrm{~kg}$ and yearlings around $11.3 \mathrm{~kg}$ (Jefferson et al. 2008). This species has one of the most confined geographic distributions among the pinnipeds; it is endemic to the Galapagos Archipelago (Fig. 1) and is mainly distributed in the northwestern region, where upwelling provides nutrient-rich waters to the ocean surface (Alava and Salazar 2006, Páez-Rosas et al. 2017). The highly productive waters and, consequently, GFS prey availability are strongly affected by the interannual variability associated with mainly El Niño/Southern Oscillation.

During an El Niño event, trade winds and the Equatorial Undercurrent patterns change and become weak (Liu et al. 2014), leading to a decrease in primary productivity and therefore fish numbers. This process is associated with the warming of surface waters as a result of weak upwelling (Chavez et al. 1999). The event affects GFS population survival in the Tropical Eastern Pacific, mostly because of prey shortage and malnutrition (Trillmich and Limberger 1985, Páez-Rosas et al. 2012). For example, the population reduction of approximately 50\% reported for $1982-1983$ and 1996-1998 was mainly attributed to strong El Niño conditions (Trillmich and Dellinger 1991, Bastida et al. 2007).

The influence of El Niño on the decrease of the GFS' main prey along the well-known established foraging areas forces the GFS to expand its feeding grounds to unusual sites, well beyond its common distribution range (Trillmich et al. 1991), leading to some individuals being sighted or stranded outside their usual range and foraging areas. The GFS has been reported on the coasts of mainland Ecuador, Colombia, and Mexico (Capella et al. 2002, Aurioles-Gamboa et al. 2004). Some unusual pinniped records have locations that are over 3,000 km away from the known distribution range and include the northernmost record for A. galapagoensis, in Michoacán, Mexico (Páez-Rosas et al. 2017). Most of the pinnipeds sighted in Mexico were identified by visual inspection and morphometric data, but this kind of assessment can be difficult as young individuals of several species are very en costas e islas (Riedman 1990). El acceso a estos recursos se ve afectado por la temperatura del océano, lo cual restringe drásticamente la distribución de las poblaciones (Trillmich et al. 1991). A pesar de las restricciones geográficas, diversos avistamientos de diferentes especies de pinnípedos han sido registrados fuera de sus áreas usuales de distribución, incluso a distancias superiores a cientos o miles de kilómetros. Algunos de estos registros atípicos en México incluyen Arctocephalus australis (Zimmerman 1783) en Oaxaca (Villegas-Zurita et al. 2016), Eumetopias jubatus (Schreber 1776) en Colima (Ceballos et al. 2010, Gallo-Reynoso et al. 2020), Zalophus wollebaeki (Sivertsen 1953) en Chiapas y Arctocephalus galapagoensis (Heller 1904) en Guerrero, Chiapas y Michoacán (Aurioles-Gamboa et al. 2004, PáezRosas et al. 2017).

El lobo fino de Galápagos (LFG), A. galapagoensis, es el más pequeño de los lobos finos. Presenta dimorfismo sexual muy sutil en comparación con otros otáridos. Los machos alcanzan tamaños de entre 1.5 y $1.6 \mathrm{~m}$ de largo y pesan entre 60.0 y $68.0 \mathrm{~kg}$. Las hembras pueden alcanzar una talla de $1.3 \mathrm{~m}$ de largo y pesan entre 21.5 y $33.0 \mathrm{~kg}$. Las crías pesan entre 3.0 y $4.0 \mathrm{~kg}$, y los individuos de alrededor de un año pesan, aproximadamente, $11.3 \mathrm{~kg}$ (Jefferson et al. 2008). Esta especie muestra una de las distribuciones geográficas más limitadas entre los pinnípedos; es endémica del archipiélago de Galápagos (Fig. 1) y se distribuye, principalmente, en la región noroeste, donde las surgencias acarrean aguas ricas en nutrientes hacia la capa superficial del océano (Alava y Salazar 2006, Páez-Rosas et al. 2017). Las aguas altamente productivas y, consecuentemente, la disposición de las presas del LFG son fuertemente afectadas por la variabilidad interanual asociada, principalmente, al fenómeno de El Niño/ Oscilación del Sur.

Durante un evento de El Niño, los vientos alisios y los patrones de la corriente subsuperficial ecuatorial cambian y se vuelven débiles (Liu et al. 2014), lo cual lleva a una disminución en la productividad primaria y, consecuentemente, en el número de peces (Chavez et al. 1999). Dicho evento afecta la supervivencia de toda la población de LFG en el Pacífico Oriental Tropical, principalmente debido a la carencia de alimento y la malnutrición (Trillmich y Limberger 1985, Páez-Rosas et al. 2012). Un ejemplo de esto fue la reducción de, aproximadamente, el $50 \%$ de la población durante 1982-1983 y 1996-1998, que fue atribuida, principalmente, a las condiciones de eventos fuertes de El Niño (Trillmich y Dellinger 1991, Bastida et al. 2007).

La influencia de El Niño en el decremento de las principales presas de LFG a lo largo de sus bien establecidas zonas de forrajeo obliga a los LFG a expandir su territorio de alimentación hacia sitios inusuales, más allá de su área de distribución normal (Trillmich et al. 1991), lo que resulta en avistamientos o varamientos de algunos individuos más allá de su distribución y zonas de alimentación habituales. La presencia del LFG ha sido reportada en las costas continentales de Ecuador, Colombia y México (Capella et al. 
similar. In such cases, the use of molecular tools allows accurate identification of species, especially during early growth stages, when diagnostic traits have not yet been developed.

On 19 May 2019, local people from La Escobilla community in Oaxaca, Mexico, reported a young pinniped individual in the Santuario Playa de Escobilla Natural Protected Area. The individual was injured and in poor condition and was thus transferred to the Centro Mexicano de la Tortuga by veterinary staff for rehabilitation, with previous authorization from the Procaduría Federal de Protección Ambiental (PROFEPA) in Oaxaca (Fig. 2). The individual was attended to by the center's veterinarians, who provided hydration and nourishment. Though it eventually gained strength and started eating on its own, after 10 days from arrival the individual suddenly died of pneumonia, as confirmed by the necropsy. We proceeded with visual inspection to confirm the species and looked for important fur seal traits such as size of head, profile shape, muzzle structure, and fur coloration. In A. galapagoensis the muzzle has a small pointy and conical nose and the pinnae are long and prominent; females are often lighter in the face and forehead (Shirihai 2006). Several photographs were taken from different angles, revealing a pointy snout of light color along with a small dark body. Though the traits resembled those of $A$. galapagoensis, given the early age and the
2002, Aurioles-Gamboa et al. 2004). Algunos de los registros atípicos de pinnípedos tienen ubicaciones de más de $3,000 \mathrm{~km}$ fuera de la distribución que ya se conoce e incluyen el avistamiento más norteño de $A$. galapagoensis, que fue registrado en Michoacán, México (Páez-Rosas et al. 2017). La mayoría de los pinnípedos observados en México fueron identificados visualmente y con datos morfométricos, pero este tipo de examinación puede ser difícil, ya que los juveniles de diversas especies son muy similares. En tales casos, el uso de marcadores moleculares permite una identificación certera de especies, especialmente durante los estadios tempranos de crecimiento, cuando aún no se han desarrollado los caracteres diagnósticos de la especie.

El 19 de mayo de 2019, habitantes de la comunidad La Escobilla en Oaxaca, México, reportaron un joven pinnípedo en el Área Natural Protegida Santuario Playa de Escobilla. El animal se encontraba herido y en mal estado, por lo que se transportó al Centro Mexicano de la Tortuga por personal veterinario para su rehabilitación, con previa autorización de la Procuraduría Federal de Protección Ambiental (PROFEPA) de Oaxaca (Fig. 2). El individuo fue atendido por el personal veterinario de este centro, quienes lo hidrataron y lo alimentaron. Aunque eventualmente recuperó fuerza y comenzó a comer por sí solo, 10 días después de su llegada, el individuo repentinamente murió de una neumonía, tal como

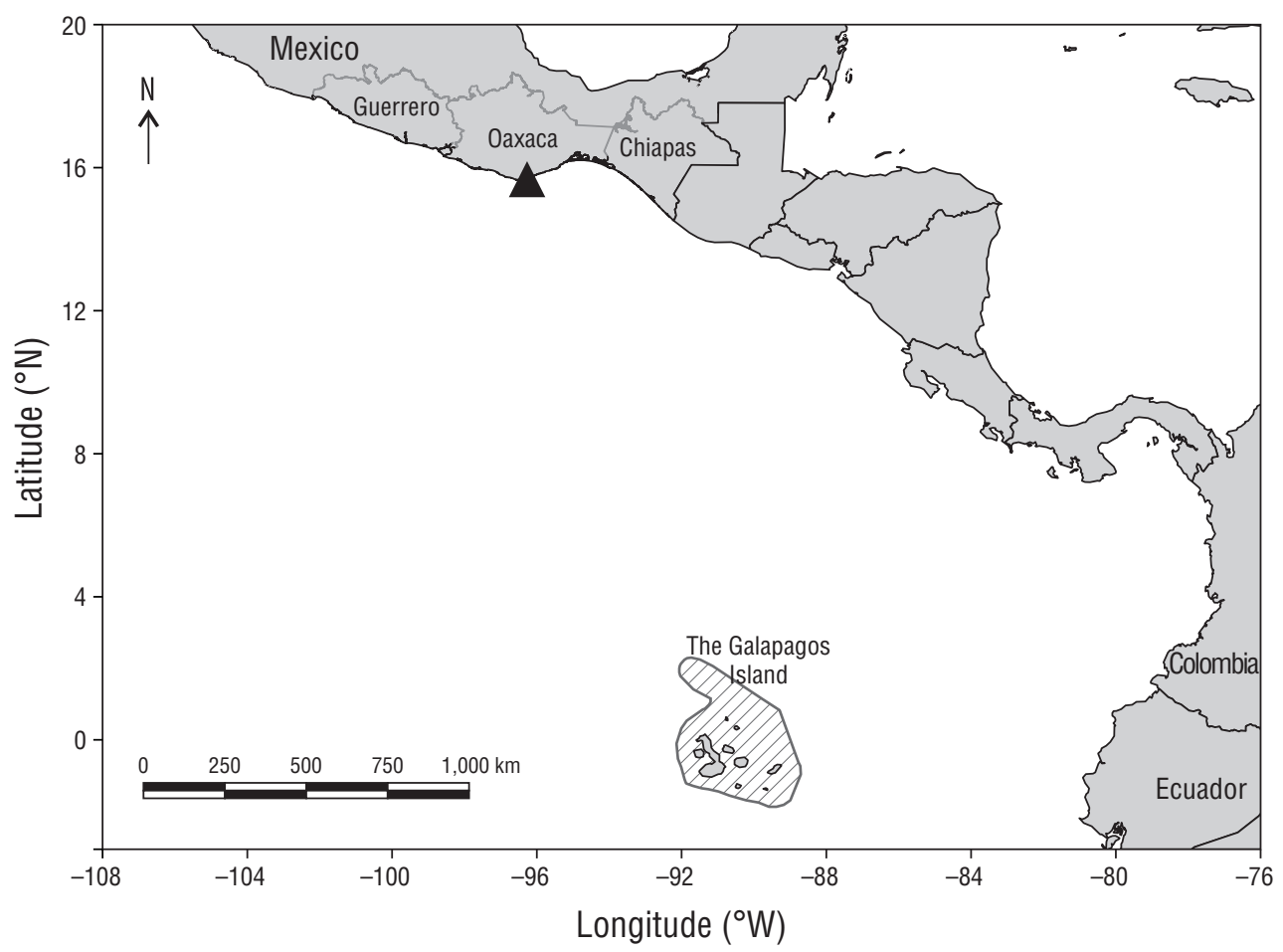

Figure 1. Distribution range of Arctocephalus galapagoensis (slanted bars) and location of the A. galapagoensis individual that stranded in Oaxaca, Mexico (triangle).

Figura 1. Área de distribución de Arctocephalus galapagoensis (barras inclinadas) y ubicación del individuo de A. galapagoensis varado en Oaxaca, México (triángulo). 


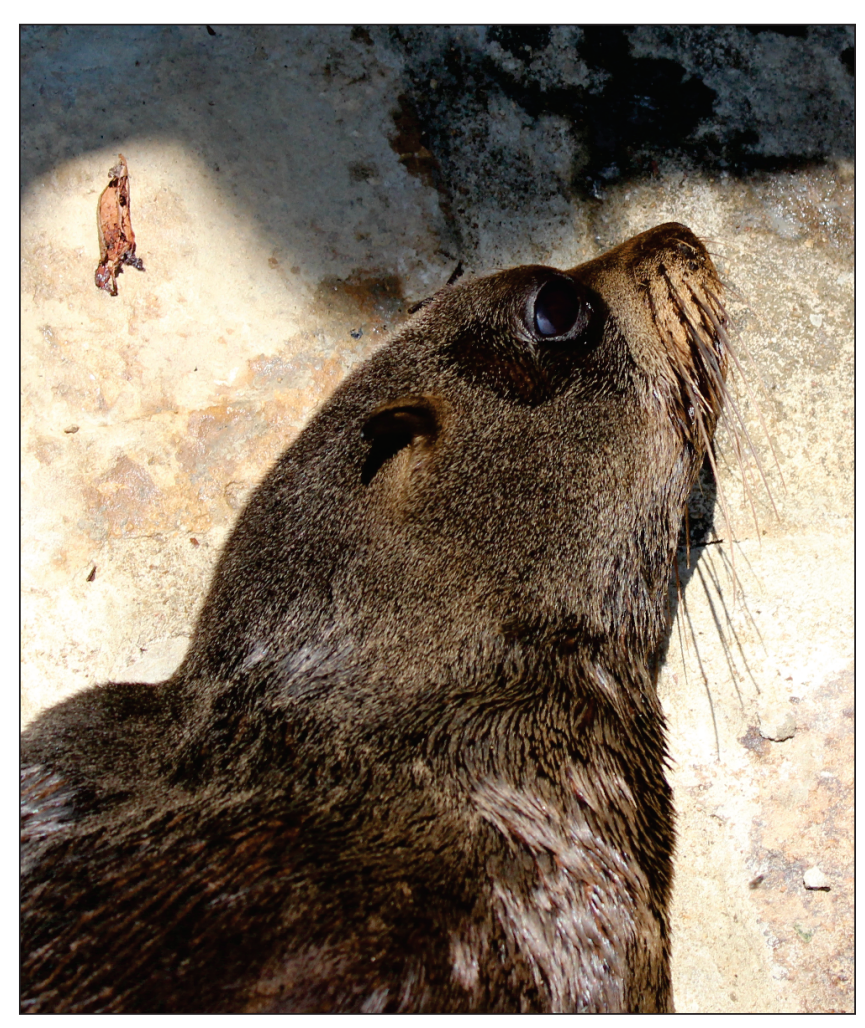

Figure 2. Arctocephalus galapagoensis individual found in $\mathrm{La}$ Escobilla community, Oaxaca, Mexico.

Figura 2. Individuo de Arctocephalus galapagoensis encontrado en la comunidad de La Escobilla, Oaxaca, México.

strong resemblance among juvenile fur seals of different species, genetic confirmation was required. This study aimed to amplify a short fragment of the specimen's mitochondrial DNA (mtDNA) control region in order to confirm the identity of the species.

\section{MATERIALS AND METHODS}

A 12-mg tissue sample from a hind flipper was kept in 97\% ethanol in a $2 \mathrm{~mL}$ Eppendorf tube. DNA was extracted from the tissue sample at the Umar Genetics Laboratory with the QIAGEN Gentra PureGene kit (Chatsworth, CA). A 660-bp fragment of the mtDNA control region was amplified with primers ZcalF (3' CCTAAGACTCAAGGAAGAAGCA 5') and ZcalR (3' TGCACCTCATGGTTGTATGA $5^{\prime}$ ), which were designed in this study using a $Z$. californianus sequence (NC_008416.1). PCR conditions were $150 \mu \mathrm{M}$ dNTPs, $1.5 \mathrm{mM} \mathrm{MgCl} 2,20 \mathrm{mM}$ Tris- $\mathrm{HCl}$ with a pH of $8.0,50 \mathrm{mM} \mathrm{KCl}, 0.3 \mu \mathrm{M}$ for each primer, $1.25 \mathrm{U} / \mu \mathrm{L}$ Taq-polimerase, and $20 \mathrm{ng}$ of DNA, with initial denaturation at $95{ }^{\circ} \mathrm{C}$ for $4 \mathrm{~min}$, followed by 30 cycles at $94{ }^{\circ} \mathrm{C}$ for $45 \mathrm{~s}$, $59^{\circ} \mathrm{C}$ for $1 \mathrm{~min}$, and $72{ }^{\circ} \mathrm{C}$ for $1 \mathrm{~min}$, and final extension at $72{ }^{\circ} \mathrm{C}$ for $5 \mathrm{~min}$. PCR products were checked for integrity and concentration in $2 \%$ agarose gels dyed with ethidium lo confirmó la necropsia. Se llevó a cabo una inspección visual para confirmar la especie, y se buscaron los caracteres diagnósticos importantes del lobo fino, como el tamaño de la cabeza, la forma del perfil, la estructura del hocico y la coloración del pelaje. En A. galapagoensis, el hocico consta de una nariz cónica, punteada y pequeña, y las orejas son largas y prominentes; por lo general, la frente y la cara son de coloración más clara en las hembras (Shirihai 2006). Se tomaron diversas fotografías desde diferentes ángulos y revelaron un hocico puntiagudo de color claro y un cuerpo pequeño y oscuro. Aunque estos rasgos semejan a los de A. galapagoensis, debido a la corta edad del individuo y al gran parecido entre juveniles de diferentes especies de lobo fino, era necesario obtener una confirmación genética. Por tanto, el objetivo de este estudio fue amplificar un fragmento corto de la región control del ADN mitocondrial (ADNmt) con el fin de confirmar la identidad de la especie.

\section{MATERIALES Y MÉTODOS}

Una muestra de tejido de $12 \mathrm{mg}$ de una aleta posterior se preservó en etanol al 97\% en un tubo Eppendorf de $2 \mathrm{~mL}$. El ADN fue extraído a partir de la muestra de tejido en el laboratorio de Genética de la Universidad del Mar con un kit Gentra PureGene de QIAGEN (Chatsworth, CA). Se amplificó un fragmento de $660 \mathrm{pb}$ de la región control del ADNmt con los cebadores ZcalF (3'CCTAAGACTCAAGGAAGAAGCA5') y ZcalR (3'TGCACCTCATGGTTGTATGA5'), los cuales fueron diseñados en este estudio a partir de una secuencia de Z. californianus (NC_008416.1). Las condiciones de la PCR fueron las siguientes: $150 \mu \mathrm{M}$ de dNTP, $1.5 \mathrm{mM}$ de $\mathrm{MgCl}_{2}, 20 \mathrm{mM}$ de Tris- $\mathrm{HCl}$ con $\mathrm{pH}$ de $8.0,50 \mathrm{mM}$ de $\mathrm{KCl}, 0.3 \mu \mathrm{M}$ para cada cebador, $1.25 \mathrm{U} / \mu \mathrm{L}$ de taq polimerasa y $20 \mathrm{ng}$ de ADN, con una desnaturalización inicial a $95{ }^{\circ} \mathrm{C}$ por $4 \mathrm{~min}$, seguida de 30 ciclos a $94{ }^{\circ} \mathrm{C}$ por $45 \mathrm{~s}$, a $59{ }^{\circ} \mathrm{C}$ por $1 \mathrm{~min}$, y a $72{ }^{\circ} \mathrm{C}$ por $1 \mathrm{~min}$ y una extensión final a $72^{\circ} \mathrm{C}$ por $5 \mathrm{~min}$. La integridad y la concentración de los productos de la PCR se revisaron en geles de agarosa al $2 \%$ teñidos con bromuro de etidio, y $5 \mu \mathrm{L}$ del producto de la PCR restante fueron enviados para una secuenciación de Sanger en un secuenciador automático Applied Biosystems 3730xl (arreglos capilares de $50 \mathrm{~cm}$ ) en el Core DNA Sequencing Facility de la University of Illinois Urbana-Champaign.

Las secuencias directas e inversas obtenidas se revisaron visualmente para realizar el control de calidad y se alinearon con el software Bioedit v.7.0.5 para obtener un fragmento consenso (UM71). Se obtuvieron del GenBank diversas secuencias de la región control de otras especies de lobo fino y se alinearon junto con la secuencia obtenida en este estudio (ver Fig. 3 para ver los números de acceso de las secuencias). Se construyó un árbol de parsimonia con un soporte de remuestreo de 500 repeticiones en MEGA 7 (Tamura et al. 2007), y se usó el lobo marino de California, Z. californianus, como grupo externo. 
bromide, and $5 \mu \mathrm{L}$ of the remaining PCR product were sent for Sanger dideoxy sequencing in an Applied Biosystems $3730 x 1$ automated sequencer $(50 \mathrm{~cm}$ capillary array) in the Core DNA Sequencing Facility at the University of Illinois Urbana-Champaign.

The obtained forward and reverse sequences were checked by eye for quality control and aligned with the software Bioedit v.7.0.5 to obtain a forward consensus fragment (UM71). Several control region sequences from other fur seal species were taken from GenBank and added to the alignment (see Fig. 3 for accession numbers). A parsimony tree was constructed with a bootstrap support of 500 repetitions using MEGA 7 (Tamura et al. 2007), and the California sea lion, Z. californianus, was used as an outgroup.

\section{Results}

Inspection of the genital area of the stranded pinniped confirmed that it was a female. The individual weighed $10.8 \mathrm{~kg}$ and measured $91 \mathrm{~cm}$ total curvilinear length and $87 \mathrm{~cm}$ total length. Data collected from free-ranging individuals at the Galapagos Archipelago indicate that mean weight of one-year-old females is $9.5 \mathrm{~kg}$ in an ordinary year and $12.1 \mathrm{~kg}$ in a good year (Trillmich 1986); therefore, the individual stranded in Oaxaca was approximately one year old. The tree obtained from the mtDNA control region clustered the specimen's sequence (UM71) (GenBank accession number: MT992621) within the GFS, A. galapagoensis, group (Fig. 3).

\section{Discussion}

Stranded individuals provide invaluable information regarding the distribution, ecology, and health of marine mammals, especially in regions where the study of these animals is limited. Stranding events become the first effort in the compilation of regional checklists that could constitute the baseline to document historical changes in species distribution, behavior, and dispersal due to changing natural conditions. Visual identification of marine mammals requires a level of expertise that is limited to highly trained individuals, limiting the proper documentation of atypical sightings. Additionally, young individuals lack diagnostic species traits, occasionally making it impossible for experts to determine species visually. This note documents the first record of A. galapagoensis on the coast of Oaxaca, Mexico, by means of a DNA analysis, allowing for species assignment even when diagnostic characteristics are not clear. Molecular tools can prevent misidentification of sightings, especially during pinniped early growth stages. DNA analysis has been used in some cases (Aurioles-Gamboa et al. 2004); however, it has not become a standardized tool for species identification during rare sightings and strandings (Ceballos et al. 2010, Gallo-Reynoso et al. 2020), which could be due to the cost and time to process the sample.

\section{RESUltados}

En la inspección del área genital del pinnípedo varado se confirmó que era una hembra. El individuo pesó $10.8 \mathrm{~kg}$ y midió $91 \mathrm{~cm}$ de largo curvilíneo total y $87 \mathrm{~cm}$ de largo recto total. Datos recolectados a partir de individuos de vida libre en el archipiélago de Galápagos indican que el peso medio de las hembras de un año de edad es de $9.5 \mathrm{~kg}$ en un año ordinario y $12.1 \mathrm{~kg}$ en un buen año (Trillmich 1986). Por lo cual, se puede suponer que el individuo que se varó en Oaxaca era de aproximadamente un año de edad. El árbol obtenido a partir de la región control del ADNmt agrupó la secuencia obtenida en este trabajo (UM71) (número de acceso del GenBank: MT992621) con las secuencias de los LFG, A. galapagoensis (Fig. 3).

\section{Discusión}

Los individuos varados proveen información invaluable sobre la distribución, la ecología y la salud de los mamíferos marinos, especialmente en regiones donde el estudio de estas especies está limitado. Los varamientos se han convertido en el primer esfuerzo por compilar listados regionales que podrían constituir la base de la documentación de cambios históricos en la distribución, el comportamiento y la dispersión de especies debidos al cambio en las condiciones naturales. La identificación visual de estas especies requiere de un nivel de pericia que está restringido a personal altamente calificado, lo que limita el poder de la documentación de avistamientos atípicos. Adicionalmente, los individuos jóvenes carecen de los caracteres diagnósticos de la especie, lo que ocasionalmente hace imposible la determinación de manera visual, incluso por los expertos. Esta nota documenta el primer registro de A. galapagoensis en la costa de Oaxaca, México, por medio de un análisis de ADN, que permite la determinación de especies incluso cuando los caracteres diagnósticos no son claros. Las herramientas moleculares pueden prevenir la identificación errónea de los avistamientos, especialmente durante las etapas tempranas de crecimiento de los pinnípedos. El análisis de ADN ha sido empleado en algunos casos (Aurioles-Gamboa et al. 2004); sin embargo, no se ha convertido en una herramienta estandarizada en la identificación de especies durante avistamientos extraordinarios y varamientos (Ceballos et al. 2010, Gallo-Reynoso et al. 2020), lo cual puede ser atribuido al costo y al tiempo para procesar la muestra.

El LFG identificado en este estudio por medio del análisis de ADNmt fue uno de al menos 4 avistamientos de pinnípedos juveniles ocurridos con unos cuantos días de diferencia. El primero fue reportado y fotografiado por miembros de la comunidad el Paraje Brinca Perros, El Coyul, en el municipio de San Pedro Huamelula ( $\left(15^{\circ} 51^{\prime} \mathrm{N}, 95^{\circ} 48^{\prime} \mathrm{W}\right)$, Oaxaca, el 15 de mayo de 2019. Otro reporte ocurrió el 17 de mayo en la localidad de Cuatunalco, en el municipio de Pochutla (aproximadamente a $64 \mathrm{~km}$ del primer avistamiento). El 


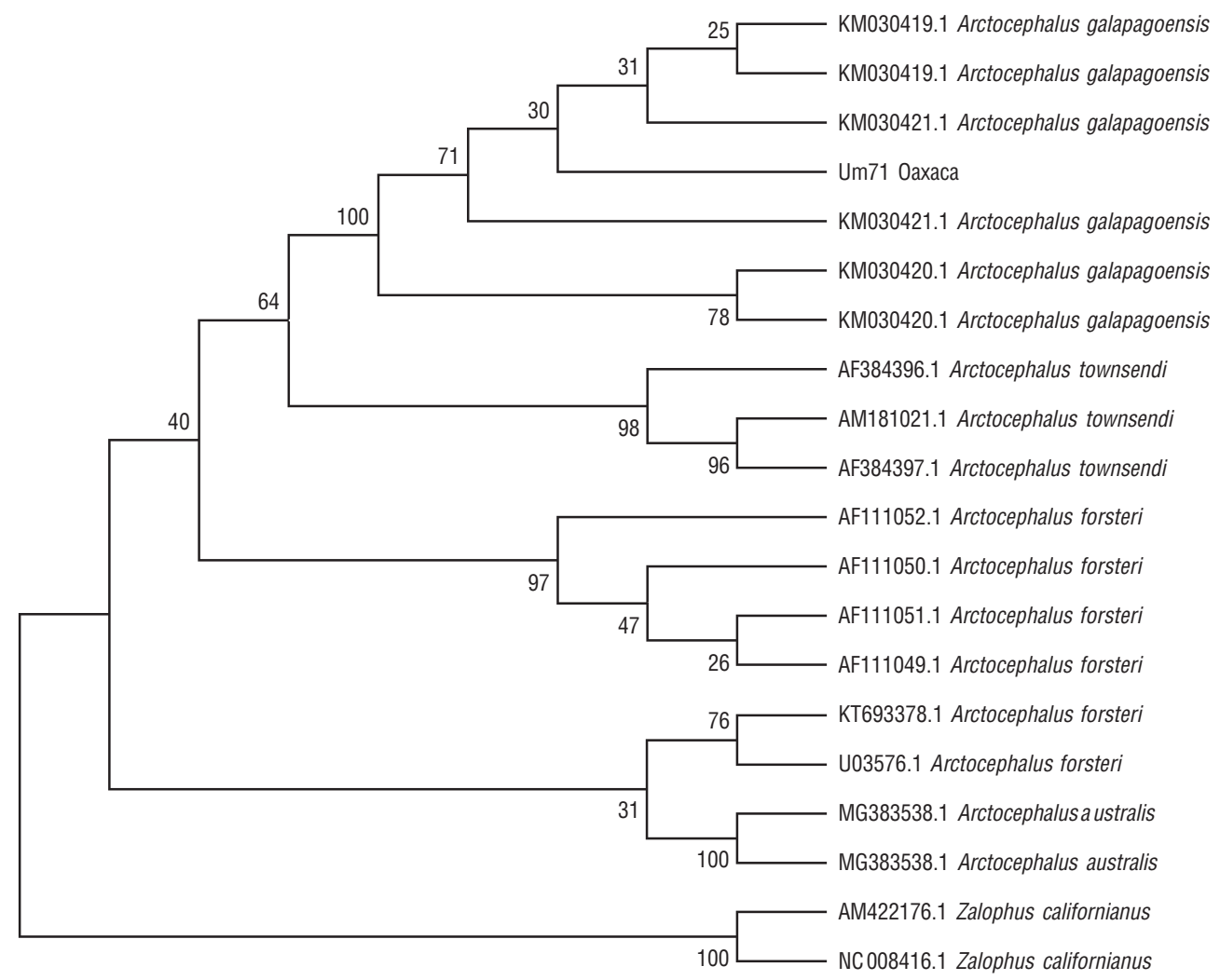

Figure 3. Parsimony tree with 500 bootstrap repetitions. The sequenced individual (UM71 Oaxaca) is shown within the A. galapagoensis clade. Genbank access numbers for each sequence are shown in the label.

Figura 3. Árbol de parsimonia con 500 réplicas de remuestreo. El individuo secuenciado (UM71 Oaxaca) se muestra dentro del clado de A. galapagoensis. Los números de acceso a GenBank para cada secuencia se muestran en las etiquetas.

The GFS identified in this study by mtDNA analysis was one of at least 4 separate sightings of juvenile pinnipeds that occurred within a few days apart. The first one was reported and photographed by members of the community in Paraje Brinca Perros, El Coyul, in the municipality of San Pedro Huamelula ( $\left.15^{\circ} 51^{\prime} \mathrm{N}, 95^{\circ} 48^{\prime} \mathrm{W}\right)$, Oaxaca, on 15 May 2019. Another report followed on 17 May at the locality of Cuatunalco, in the municipality of Pochutla (approximately $64 \mathrm{~km}$ from the first sighting). The subject of this study was reported on 19 May in the Santuario Playa de Escobilla Natural Protected Area $\left(15^{\circ} 43^{\prime} \mathrm{N}, 96^{\circ} 44^{\prime} \mathrm{W}\right)$ (approximately $70 \mathrm{~km}$ from the second sighting). In addition, on 23 May, another small juvenile with the same physical characteristics was sighted weak and trying to get back into the water in the Lagunas de Chacahua Natural Protected Area, in the locality of Barra Quebrada (15 $\left.58^{\prime} \mathrm{N}, 97^{\circ} 40^{\prime} \mathrm{W}\right)$, El Azufre, in the municipality of San Pedro Tututepec.

A possible explanation for the presence of A. galapagoensis in the Pacific coast of southern Mexico could be the effects of an El Niño event. According to the US National Oceanic and Atmospheric Administration's National Weather Service-Climate Prediction Center, an El Niño event took place in October 2018 and continued through July 2019 individuo analizado en este estudio fue reportado el 19 de mayo en el Área Natural Protegida Santuario Playa de Escobilla $\left(15^{\circ} 43^{\prime} \mathrm{N}, 96^{\circ} 44^{\prime} \mathrm{W}\right)$ (aproximadamente a $70 \mathrm{~km}$ del segundo avistamiento). Adicionalmente, el 23 de mayo, otro juvenil con las mismas características físicas fue observado débil y tratando de regresar al agua en el Área Natural Protegida Lagunas de Chacahua, en la localidad de Barra

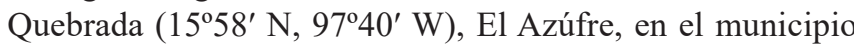
de San Pedro Tututepec.

Una posible explicación de la presencia de $A$. galapagoensis en la costa del Pacífico del sur de México podría ser los efectos de un evento El Niño. De acuerdo con el Centro de Predicción Climática del Servicio Nacional de Meteorología de la Oficina Nacional de Administración Oceánica y Atmosférica de los Estados Unidos, un evento de El Niño inició en octubre de 2018 y continuó en el hemisferio norte hasta julio de 2019 (https://origin.cpc.ncep.noaa.gov/products/ analysis_monitoring/ensostuff/ONI_v5.php). Los cambios en la temperatura superficial del mar fueron evidentes en la región del archipiélago de Galápagos (Fig. 4). Esto sugiere que durante mayo de 2019 hubo una presencia atípica de LFG de un año de edad en la costa suroriental de México, lo cual probablemente llevó al primer registro de esta especie, 
in the Northern Hemisphere (https://origin.cpc.ncep.noaa. gov/products/analysis_monitoring/ensostuff/ONI_v5.php). Changes in sea surface temperature were evident in the Galapagos Archipelago region (Fig. 4). In May 2019 there could have been an atypical presence of GFS yearlings on the southeastern coast of Mexico, which is what probably lead to the first record of this species, confirmed with DNA analysis, on the coasts of Oaxaca.

Sightings of GFS beyond their usual range have been reported in recent years, most of them adults in good body condition (Páez-Rosas et al. 2017). In 1998, 2 juvenile GFSs in poor condition were reported by Aurioles-Gamboa et al. (2004) in the southern Mexican states of Guerrero and Chiapas. GFSs show a single foraging strategy, which consists in covering large foraging areas with shallow dives associated confirmado a través de un análisis de ADN, en las costas de Oaxaca.

En años recientes, se han reportado avistamientos de LFG fuera de su distribución habitual, la mayoría de ellos adultos en buenas condiciones (Páez-Rosas et al. 2017). En 1998, 2 LFG juveniles en mal estado fueron reportados por Aurioles-Gamboa et al. (2004) en los estados mexicanos sureños de Guerrero y Chiapas. Los LFG muestran una estrategia única de forrajeo, que consiste en cubrir grandes áreas con buceos someros y relacionados con los ciclos lunares, mientras que los lobos marinos de Galápagos muestran diversas estrategias de forrajeo (buceos someros y profundos) en un área más pequeña (Villegas-Amtmann et al. 2013). Aun cuando existe la segregación de nichos entre estas 2 especies, se ha documentado un traslapo relacionado

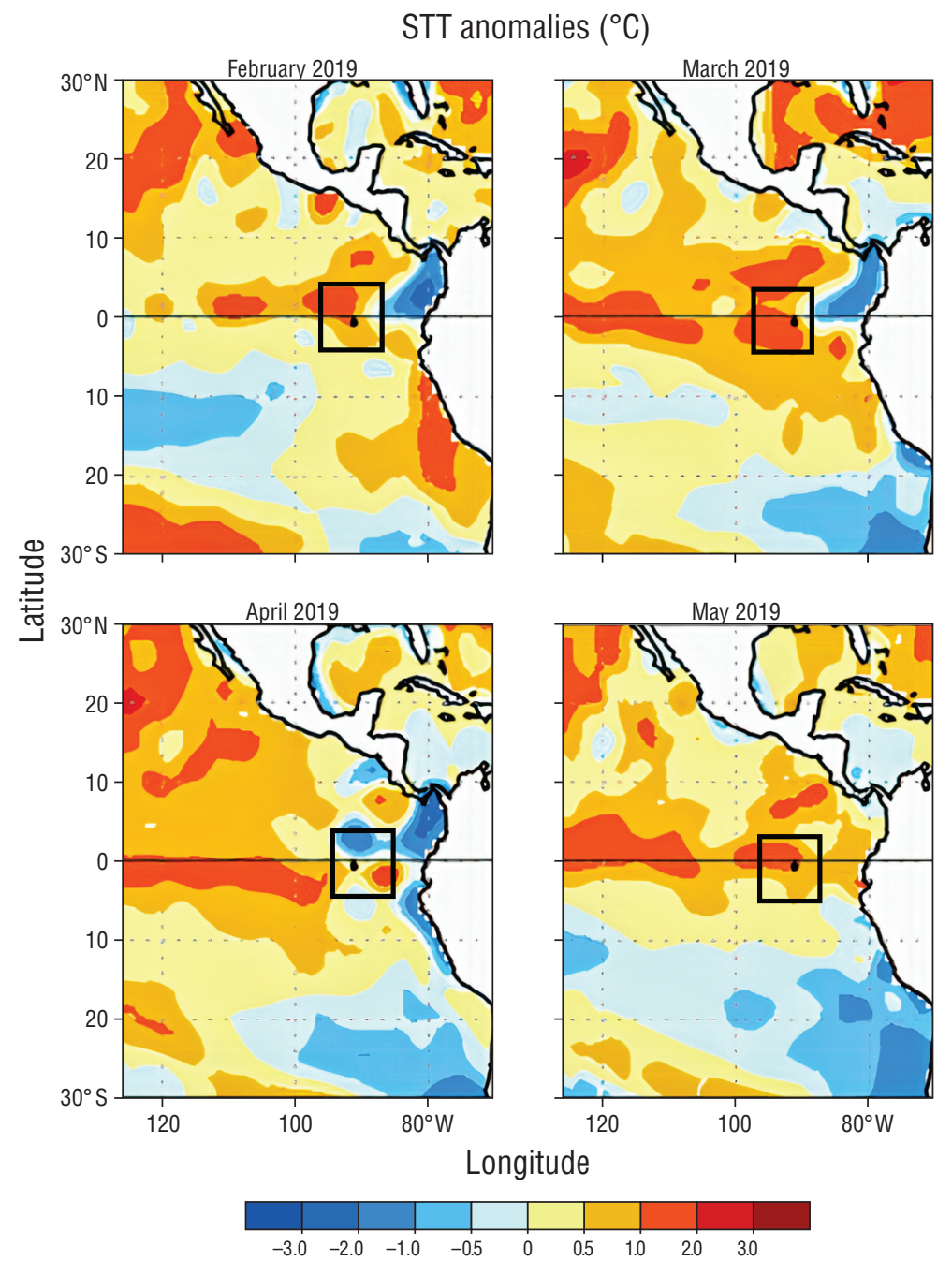

Figure 4. Average sea surface temperature (SST) anomalies $\left({ }^{\circ} \mathrm{C}\right)$ for the week centered for each month (February, March, April, and May). Anomalies are computed with respect to the 1981-2010 base period weekly means. Images taken from https://www.cpc.ncep.noaa.gov/ products/expert_assessment/ENSO_DD_archive.php. The square shows the location of the Galapagos Archipelago.

Figura 4. Anomalías de la temperatura superficial del mar (SST, $\left.{ }^{\circ} \mathrm{C}\right)$ media para la semana centrada en cada mes (febrero, marzo, abril y mayo). Las anomalías se calculan con respecto a las medias semanales del periodo base 1981-2010. Imágenes tomadas de https://www.cpc. ncep.noaa.gov/products/expert_assessment/ENSO_DD_archive.php. El cuadro muestra la ubicación del archipiélago de Galápagos. 
with lunar cycles, while Galapagos sea lions show several foraging strategies (shallow and deep dives) in a smaller area (Villegas-Amtmann et al. 2013). While there is niche segregation between both species, some overlapping has been documented and related to moderate El Niño conditions, with warm water and decreased prey availability (Páez-Rosas et al. 2012). It is possible that in warmer years the competition between both species becomes stronger and drives fur seals to perform farther foraging trips, as they have to cover a larger territory because of their unique foraging strategy, causing them to get lost and tired and prone to being caught in an ocean current. This anomalous situation could be enhanced by high sea surface temperatures due to El Niño events, as previously mentioned by Páez-Rosas et al. (2017). Considering that climate change scenarios predict constant rises in global temperature, the protection of this species requires a coordinated effort between several countries to document and properly identify the atypical presence of this vulnerable species.

\section{ACKNOWLEDGMENTS}

The tissue sample was collected under permit SGPA/ DGVS009513/18 by the Division of Wildlife of the Ministry of Environment and Natural Resources (Mexico). The Oaxaca Stranding Network coordinated the response to rescue the injured individual. We are especially grateful to the PROFEPA delegate in Oaxaca, Héctor Hugo Miranda, for organizing all efforts. We thank members of La Escobilla community. The Centro Mexicano de la Tortuga facilitated staff and all resources. The Mexican Association of Habitats for the Interaction and Protection of Marine Mammals (AMHAR, for its acronym in Spanish) sent specialized veterinarians (Larissa Serrano and María Renée Arreola) and provided medical care. We also thank volunteer veterinarian Henghis Serna, who selflessly helped with medical care, and the Universidad del Mar students, who provided help and covered night watches. A very special mention to Fernando Elorriaga-Verplancken for the guidance and recommendations and to Diego Páez-Rosas of the San Francisco de Quito University, Ecuador, for the identification of the species through photographic material.

\section{REFERENCES}

Alava JJ, Salazar S. 2006. Status and Conservation of Otariids in Ecuador and the Galápagos Islands. In: Trites AW, Atkinson SK, DeMaster DP, Fritz LW, Gelatt TS, Rea LD, Wynne KM (eds.), Sea Lions of the World. Fairbanks (USA). Alaska: Alaska Sea Grant College Program, University of Alaska. p. 495-519. https://doi.org/10.4027/slw.2006

Aurioles-Gamboa D, Schramm Y, Mesnick S. 2004. Galapagos fur seals, Arctocephalus galapagoensis, in Mexico. Lat Am J Aquat Mamm. 3(1):77-80.

https://doi.org/10.5597/lajam00051

Bastida R, Rodríguez D, Secchi-Vera da Silva E. 2007. Mamíferos Acuáticos de Sudamérica y Antártida. Buenos Aires (Argentina): Vazquez Mazzini Ed. 366 p. con condiciones moderadas de El Niño, con aguas cálidas y decremento en la disponibilidad de presas (Páez-Rosas et al. 2012). Es posible que, en años más cálidos, la competencia entre las 2 especies crece y obliga a los lobos finos a realizar viajes de alimentación más lejanos para cubrir un mayor territorio, debido a su estrategia única de forrajeo, lo que puede causar que se cansen y se pierdan y sean susceptibles a ser atrapados en una corriente oceánica. Esta situación anómala podría ser mayor debido a las altas temperaturas superficiales del mar en eventos El Niño, como lo mencionó previamente Páez-Rosas et al. (2017). Considerando que los escenarios de cambio climático predicen aumentos constantes en la temperatura global, la protección de esta especie requiere de un esfuerzo coordinado entre diversos países para documentar e identificar adecuadamente la presencia atípica de esta especie vulnerable.

\section{Agradecimientos}

La muestra de tejido fue recolectada bajo el permiso de colecta SGPA/DGVS009513/18 de la División General de Vida Silvestre de laSecretaría de Medio Ambiente y Recursos Naturales (México). La respuesta de rescate y atención del individuo herido fue coordinada por la red de varamientos del estado de Oaxaca. Estamos particularmente agradecidos con el delegado de PROFEPA en Oaxaca, Héctor Hugo Miranda, por organizar el esfuerzo. Agradecemos a los miembros de la comunidad de La Escobilla. El Centro Mexicano de la Tortuga facilitó al personal y los recursos. La Asociación Mexicana de Hábitats para la Interacción y Protección de Mamíferos Marinos (AMHAR) envió personal veterinario especializado en la atención de mamíferos marinos (Larissa Serrano y María Renée Arreola) y proporcionó cuidados médicos. También agradecemos al veterinario Henghis Serna, quien generosamente ayudó con el cuidado médico, y a todos los estudiantes de la Universidad del Mar, quienes apoyaron con cuidados y guardias nocturnas. Una mención especial a Fernando Elorriaga-Verplancken, por la guía y las recomendaciones, y a Diego Páez-Rosas de la Universidad de San Francisco de Quito, Ecuador, por la identificación de la especie a través de material fotográfico.

Capella JJ, Flórez-González L, Falk-Fernández P, Palacios DM. 2002. Regular appearance of otariid pinnipeds along the Colombian Pacific coast. Aquat Mamm. 28(1):67-72.

Ceballos G, Pompa S, Espinoza E, García A. 2010. Extralimital distribution of Galapagos (Zalophus wollebaeki) and northern (Eumetopias jubatus) sea lions in Mexico. Aquat Mamm. 36(2):188-194.

https://doi.org/10.1578/AM.36.2.2010.188

Chavez FP, Strutton PG, Friederich GE, Feely RA, Feldman GC, Foley DG, McPhaden MJ. 1999. Biological and chemical response of the equatorial Pacific Ocean to the 1997-98 El Niño. Science. 286(5447):2126-2131.

https://doi.org/10.1126/science.286.5447.2126 
Gallo-Reynoso JP, Figueroa-Carranza AL, Barba-Acuña ID, Borjes-Flores D, Pérez-Cossío IJ. 2020. Steller sea lions (Eumetopias jubatus) along the western coast of Mexico. Aquat Mamm. 46(4):411-416.

https://doi.org/10.1578/AM.46.4.2020.411

Jefferson TA, Webber MA, Pitman RL, Jarrett B. 2008. Marine Mammals of the World: A Comprehensive Guide to Their Identification. Amsterdam: Elsevier, Academic Press. 592 p.

Liu Y, Xie L, Morrison JM, Kamykowski D, Sweet WV. 2014. Ocean circulation and water mass characteristics around the Galápagos Archipelago simulated by a multiscale nested ocean circulation model. Int J Oceanogr. 2014:198686. https://doi.org/10.1155/2014/198686

Páez-Rosas D, Aurioles-Gamboa D, Alava JJ, Palacios DM. 2012. Stable isotopes indicate differing foraging strategies in two sympatric otariids of the Galapagos Islands. J Exp Mar Bio Ecol. 424-425:44-52.

https://doi.org/10.1016/j.jembe.2012.05.001

Páez-Rosas D, Valdovinos LA, Elorriaga-Verplancken FR. 2017. Northernmost record of the Galapagos fur seal (Arctocephalus galapagoensis): A consequence of anomalous warm conditions around the Galapagos Archipelago. Aquat Mamm. 43(6):629-634. https://doi.org/10.1578/AM.43.6.2017.629

Riedman M. 1990. The Pinnipeds: Seals, Sea Lions and Walruses. 2nd ed. Oxford: Oxford University Press. 439 p.

Shirihai H. 2006. Whales, Dolphins and Seals: A Field Guide to the Marine Mammals of the World. London (UK): A \& C Black. 384 p.

Tamura K, Dudley J, Nei M, Kumar S. 2007. MEGA4: Molecular Evolutionary Genetics Analysis (MEGA) software version 4.0.
Mol Biol Evol. 24(8):1596-1599.

https://doi.org/10.1093/molbev/msm092

Trillmich F. 1986. Maternal investment and sex-allocation in the Galapagos fur seal, Arctocephalus galapagoensis. Behav Ecol Sociobiol. 19(3):157-164.

Trillmich F, Dellinger T. 1991. The effects of El Niño on Galapagos pinnipeds. In: Trillmich F, Ono KA (eds.), Pinnipeds and El Niño. Ecological Studies (Analysis and Synthesis), vol. 88. Berlin (Germany): Springer, Berlin, Heidelberg. p. 66-74. https://doi.org/10.1007/978-3-642-76398-4_7

Trillmich F, Limberger D. 1985. Drastic effects of El Niño on Galapagos pinnipeds. Oecologia. 67(1):19-22. https://doi.org/10.1007/BF00378445

Trillmich F, Ono KA, Costa DP, DeLong RL, Feldkamp SD, Francis JM, Gentry RL, Heath CB, LeBoeuf BJ, Majluf P, et al. 1991. The effects of El Niño on pinniped populations in the Eastern Pacific. In: Trillmich F, Ono KA (eds.), Pinnipeds and El Niño. Ecological Studies (Analysis and Synthesis), vol. 88. Berlin (Germany): Springer, Berlin, Heidelberg. p. 247-270. https://doi.org/10.1007/978-3-642-76398-4_27

Villegas-Amtmann S, Jeglinski JWE, Costa DP, Robinson PW, Trillmich F. 2013. Individual foraging strategies reveal niche overlap between endangered Galapagos pinnipeds. PLOS ONE. 8(8):e70748. https://doi.org/10.1371/journal.pone.0070748

Villegas-Zurita F, Elorriaga-Verplancken FR, Castillejos-Moguel F. 2016. First report of a South American fur seal (Arctocephalus australis) in Mexico. Aquat Mamm. 42(1):42-46. https://doi.org/10.1578/AM.42.1.2016.42

Received 7 July 2020, accepted 12 October 2020. 